\title{
Coerced loss of national colorings - linguistic issues of virtual team communication
}

\author{
Irina V. Privalova - Albina R. Shaidullina - Marina R. Zheltukhina - \\ Tatyana E. Grinberg - Conchita Garcia Caselles
}

DOI: 10.18355/XL.2019.12.01.12

\begin{abstract}
This article discusses the loss of national colorings in verbal interactions of virtual team members who represent different cultures and nationalities in global communication. The tendencies to professional communication uniformity and integrity have been noted. As well, the trend to simplification of the verbal elements used in the speech of virtual team workers is marked. The research method can be described as a complex (or mixed) one since it has included a series of different approaches. Material for investigation comprises two sources. First, the questionnaire was asked to be completed by 103 workers who had an experience of work as virtual team members in various businesses. Then, the examination of short abstracts of the professional communication of the virtual team members (742 verbal units) has been conducted. The results of this research will clarify the pros and cons of language matter unification for the efficacy of business communication in international companies operating all over the world.
\end{abstract}

Key words: virtual team, virtual team communication, communication styles, language matter, cultural differences

\section{Introduction}

In this part of the article, the concept of such notion as "virtual team" will be outlined within a special emphasis on the communication activity in the era of new technologies and on the verbal matter that is most commonly exploited in this professional micro-union.

An indispensable condition for the functioning of a virtual team is the synchronous development of information technologies and globalization trends. Those are the main conditions of successful virtual team operation. Globalization trends of the $21^{\text {st }}$ century and the new digital technologies advancement are interrelated processes: IT improvements hasten up globalization pace, and, in their turn, globalization effects promote the distribution of new technologies all over the world (Firsova et al., 2018). Due to the globalization processes in cultural, social, political and economic spheres, the integration of the countries has reached a new level (Velieva et al., 2018).

Now, there are quite a lot of definitions of the concept of "globalization", meanwhile, in all these concepts the fact of strengthening ties among the states, countries and communities is underlined. The phenomenon of "strengthening ties" may also be termed as a fast-growing interconnectedness and interdependence among individuals and peoples. For instance, the British sociologist A. Giddens (2009) has emphasized the fact of interdependence at the level of individuals, groups and nations, which leads to awareness that we all live in a single world: «Globalisation refers to the fact that we all increasingly live in one world, so that individuals, groups and nations become ever more interdependent» (Giddens, 2009, p. 128). James Cameron argues that globalization foremost means the integration of previously disunited nations: «Globalization refers to the process by which previously isolated nations have become interconnected» (Cameron, 2008, p. 63). Although it would be wrong to say, that globalization is the product of the last decades only. There are scientists, and $\mathrm{N}$. Chanda (2007) is among them, who assert that globalization is a natural course of the

XLinguae, Volume 12 Issue 1, January 2019, ISSN 1337-8384, eISSN 2453-711X 
humanity's development: «...globalization stems, among other things, from a basic human urge to seek a better and more fulfilling life» (Chanda, 2007). The phenomenon of globalization is very well investigated from sociological and historical points of view; and there have been singled out several "stages", "cycles", "waves" in this process (Lechner, 2009, Ritzer, 2010, Steger 2010). Notably, globalization of the last decade is also called the "the new era of globalization" and for a reason. If the earlier stages of globalization were triggered by natural causes, then, the last stage was initiated by the fast development of new computer technologies.

New technologies allow generating the new types of communication channels, which provide greater opportunities for interlocutors. The appearance of these channels has reshaped the whole essence of the communication process. Besides, it has opened versatile opportunities for interpersonal, business and organizational communication. Fair enough, it was the Canadian sociologist Marshall McLuhan who first outlined that a globalized world's community would be the outcome of the new technologies spread (McLuhan, 1962, 1964). McLuhan's astounding prophecy that along with the change of communication channels, through which information circulates, there happen changes in the essence of the information filling these channels. The reasonableness of this observation has become especially obvious with the advent of the platforms with user-generated content, where authors of messages act as well as recipients. Indeed, communication channels have become more powerful than messages that are transmitted via these channels. In addition, communication channels preordain the scope and the content of the transmitted information. "In a culture like ours, long accustomed to splitting and dividing all things as a means of control, it is sometimes a bit of a shock to be reminded that, in operational and practical fact, the medium is the message" (McLuhan, 1994, p. 7). Moreover, with great probability, the famous dictum "medium is the message" can be applied to the situation with the communication in virtual teams.

The digital format has changed the modes of human speech perception and human speech production - it has become easy and fast to get any information in an instance. Technically determined ways of communication have brought forth new discourse practices. For instance, new kinds of digital messages have appeared (texting, chats in forums and social nets, video communication via special platforms like Skype or messengers like WhatsApp, Viber, Telegram, etc). Noteworthy, new digital technologies aimed at making remote computer communication as close as possible to natural communication. "Digitalization" affects all spheres of life, including business sphere where fast internet communication helps to address challenges. It is hard to deny that the business environment is highly "digitalized" nowadays (Chaffey, 2015, Nathan, Rosso, 2014, Pagani, 2013).

So, due to the globalized character of the business and new technologies, it has become possible to execute business tasks and management from any place in the world at any time. Thanks to new electronic means, organizational communication is speedy, inexpensive and extremely effective; hence, business activity and business transactions do not require face-to-face communication any longer.

The aim of this article is to research the linguistic peculiarities of communication in virtual teams. The question is what linguistic and extra-linguistic factors affect the loss of cultural colorings in the communication of virtual team workers who represent different nationalities. Besides, it is interesting to find out to what extent the factors of geographical dispersion and differences in business communication styles are eliminated under the influence of unification trend caused by globalization, which is accelerated owing to the use of new electronic gadgets. The results of this survey will fill in the gaps in the theoretical understanding of the globalization influence on different areas of life including language in business communication. 
In the term "virtual team", three aspects are of utmost importance: geographically scattered location of the members of a team, their connection via new electronic means of communication and "pigeon-hole" distribution of the working responsibilities. In order to make more salient one of these three aspects of a virtual team, different definitions are proposed. For instance, in order to emphasize the digital character of communication some researchers offer to use the term "computersupported groups" (Chidambaram, Tung, 2005), and later on "technology supported teams" (Alnuaimi, Robert, Maruping, 2010). Both of these terms underline the significant character of computer technologies in the performance of virtual working crews. Indeed, the main principle of a virtual team existence is the availability of new communication technologies, which bring together dispersed workers and give them a chance to accomplish organizational tasks (Powell, Piccoli, Ives, 2004).

The term "dispersed teams" (Bosch-Sijtsema, Sivunen, 2013; Muethel, Gehrlein, Hoegl, 2012) underlines the fact that virtually working employees are geographically scattered. Such characteristic of a virtual team as the remoteness of working places should be distinguished from the characteristic of separate task distribution. Virtual teams cannot function without precise tasks distribution among fellow-workers, and namely this feature is underlined in the definition of this phenomenon as " $a$ distributed team" (Breu, Hemingway, 2004). Notably, "virtual team" is defined as a culturally diverse organization: "Virtual teams are the group of individuals spread across different time zones, cultures, languages or, ethnicities which are united by a common goal" (Management Study Guide, 2017).

The phenomenon of "virtual team" is very complex and multifaceted; its effective study also requires the involvement of a variety of scientific approaches.

Therefore, the study of a virtual team is in the sphere of interests of such scientific areas as

1) Global Perspectives (Bourn, 2011, Bisley, 2007, Robertson, 1992, Scholte, 2005, Stiglitz, 2006);

2) Studies on Regionalism and Globalization (Beeson, 2007, Cooper, 2004, Held, McGrew, 2007),

3) Organizational and Business Communication (Cooren et al., 2013, Cooren, 2012, Choo et al., 2008),

4) Cross-Cultural Communication (Hall, Hall, 1990, Hofstede, 1991, Hofstede, 2001, Hall, 2003);

5) Strategic Management (Tidd, Bessant, 2014) and so on.

Interdisciplinary character of virtual team is obvious that is why to its research various scientific approaches should be applied: “...studies are now very diverse in terms of their disciplinary focus as VTs are now being examined in disciplines such as accounting, applied psychology, business management, communication, computer technology, education, engineering, information systems, and software design" (Gilson, Maynard, Young, 2015).

Worth noting, communication and linguistic components of the "virtual team" phenomenon is still insufficiently understood, and it attracts the attention of scientists through the study of various aspects of interpersonal communication in a virtual team, which represents a micro intercultural professional community.

Language aspects of virtual team operation come into focus of attention in link with the study of team building issues (Martins, Shalley, 2011, Mockaitis, Rose, Zettinig, 2012); as well, as the allocation of roles in virtual team to leaders and co-workers (Strang, 2011, Ruggieri, 2009). Leadership styles are reflected in the choice of strategies and tactics in communication among employees. On top, the studies of management styles in virtual teams (Pridmore, Phillips-Wren, 2011) are closely linked with communication aspects. Cross-cultural differences in virtual teams have come into the focus of investigations (Au, Marks, 2012, Anderson et al., 2007). One

XLinguae, Volume 12 Issue 1, January 2019, ISSN 1337-8384, eISSN 2453-711X 
of the characteristic features of a virtual professional team is the location of its members in various countries. The employees of a virtual team are representatives of different nationalities and cultures, so overcoming of cross-cultural differences is the key element that predetermines the success of communication.

Several years ago, it was possible to assert, "Without diminishing the importance of the reciprocal impact of ICTs on a society's development, sociocultural factors are pivotal in shaping the style and character of mediated communication in any given society. Mediated communication has cultural peculiarities and national colorings" (Privalova, 2012, p. 292). In fact, the representatives of different cultures have a different understanding of how to present information in the most effective way. The norms and the rules of behavior worked out by society are verbalized by various means of verbal communication, the study of which allows noticing differences in the speech communication of the representatives of various cultures. Noting the fact of an increasingly international online environment, K. St. Amant (2012) points out that "...there are deep-seated factors that underlie the communication practices in certain cultures" (St. Amant K., 2012, p.76). As one of such factors K. St. Amant (2012) names context - it is the setting in which interaction occurs. At this certain point, we need to refer to the theory of high and low context cultures, which has been set forth by E. Hall (2003). The type of culture in which they function - whether it is highcontext or low-context, predetermines speech behavior and communicative style. For instance, Russian communicative style is contextual: it exploits an indirect style of communication, based on assumptions and deducible knowledge. "In collectivist cultures, in-groups are well-established and members have a greater instinctive, innate understanding of each other, in part because of more shared experiences. This means that, as a rule, people don't need to spell things out or say very much to get their message across" (Culture Matters. Trainer's Guide, 1999, P. 33). Compared to Russian, American language culture refers to low-context, explicit or "I-mean-itcultures", where the body of a communicative and linguistic sign has an extremely low plurality of communicative meanings. "Direct cultures tend to be less collectivist and more individualist, with less well-developed in-groups. People lead more independent lives and have fewer shared experiences; hence, there is a less instinctive understanding of others. People need to spell things out and be more explicit, to say exactly what they mean rather than suggest or imply. There is less context, less that can be taken for granted and not explained. The spoken word carries most of the meaning; you should not read anything into what is not said or done. The goal of most communication exchanges is getting or giving information" (op. cit., p. 33). Undoubtedly, Russian linguistic culture differs from American culture by a more extensive and diverse arsenal of components of non-verbal communication means of verbal contact, including modes of treatment, introductory words and relativities (Tarde, 1969, Lapham, 1994, Thompson, 1995, Shao, 2009, Kozinets, 2010; Kozinets et al., 2010, Kietzmann et al., 2011, Grinberg, 2012, Grinberg, 2018, Garsiya-Kaseles, 2015, Chizh et al., 2016, Zheltukhina et al., 2016, Karapetyan et al., 2018, Ostrikova et al., 2018). Therefore, the success of the virtual team depends on how effectively cross-cultural differences are overcome in the process of communication. The main target of this study is to determine to what extent cross-cultural differences are eliminated in modern virtual teams and how it is manifested at the level of language and communication.

\section{Methodology}

At the present moment, practically all international and multinational companies organize virtual teams since this is the only way to perform their business activity under current globalized conditions. Moreover, the profile of the work of an international company does not matter: virtual teams are created in international companies, which use outsourced labor and schemes. Sometimes manufacturing of 
products (mainly intellectual products) may require the unification of efforts of unique specialists from different countries. In addition, in this way, international firms serve as the most convincing example of virtual teamwork, hence the specifics of crosscultural and organizational communication is extremely interesting there.

The research method can be described as a complex (or mixed) one since it has included a series of different approaches. In work, we use linguistic, anthropological and psychological approaches to the analysis of the material. Material for investigation comprises two sources. First, the questionnaire was asked to be completed by 103 workers who had an experience of work as virtual team members in various businesses. Then, the examination of short abstracts of the professional communication of the virtual team members ( 742 verbal units) has been conducted. As the theoretical underpinning of the research, there has been carried out a review of literary sources (see the list of references).

\subsection{Complex or Mixed Research Method}

Complex or mixed research method has been used for the investigation of the linguistic material of the work of a virtual team. It consisted of three stages:

1) creation of the theoretical underpinning of the research through examination of literary sources,

2) practical data collection,

3) analysis of the findings.

On the first stage, there has been carried out a review of 52 literary sources (see the list of references). Then, the multistep practical part of data collection was performed. At first, the plan of the practical research was worked out followed by the questionnaire from development. Then, the targeted group of informants was asked to participate in the interviewing and after that, the collected data have been processed. In the course of the interview, respondents were asked to evaluate some points critical for a successful communication while working in a virtual team, commentaries were encouraged. Finally, the examination of short abstracts of the professional communication of the virtual team members (742 verbal units) has been conducted. On the final stage of the practical research, the findings have been analyzed and discussed.

\subsection{Description of the Group of Respondents}

All interviewees have an experience of work in virtual teams in different international firms in different spheres (IT sector, pharmaceutical industry, educational business, banking business, manufacturing industry). There has been identified the number of informants valid enough to draw the reliable data. It was decided that 103 informants are enough to make some conclusions. It was important for us that all the respondents represented different age and gender groups and possessed different working experience. In addition, the geographical dispersion of the informant was important for us; that is why we have asked to circulate our questionnaire form via the Internet among employees working in different abroad affiliates of international businesses. Presumably, the employees working, for example, in the affiliates of one international IT company in the USA or Russia, or Belorussia may have various cultural insights on similar processes.

\section{Results and Discussion}

In the interviews, all issues of confidentiality and business ethics have been preserved. The forms were anonymous; however, it was obligatory to specify such data as gender, education, working life in general and in a certain company, as well as job tenure as a virtual team member. In addition, we were particular about working capacities and functions that is why this information was asked to be presented. The

XLinguae, Volume 12 Issue 1, January 2019, ISSN 1337-8384, eISSN 2453-711X 
questionnaire form included two parts: the first part "Demographic Data" was focused on collecting the demographic data of the respondents. It was necessary to reflect the sociological validity of the group under investigation, for this reason, there were questions clarifying the age of the respondents, their gender, and nationality. The age of the respondents was also of utmost importance. All respondents were separated into two age groups: from 25 to 40, and from 40 and older. As for their nationality, foremost, it was necessary to identify the place of their current living, in view with this, the respondents were asked to specify the country of their nationality, as well as the places of their residence and work. The extremely relevant information was concerning the educational and working statuses of the informants so they were asked to elaborate on the question of their education whether it was a college or a vocational training, Bachelor or a five-year university training, Masters in the process of getting this degree, or Candidate of Science or $\mathrm{PhD}$ or in the process of getting this degree. The part "Demographic Data" has helped to get an idea about the professional background of the informants so far it can crucially influence the productive performance of a virtual team. Overall, we have interviewed 103 employees with experience of work in virtual teams in various international firms.

Table 1: Demographic Data: employees with experience of work in virtual teams in various international firms

\begin{tabular}{|c|c|c|c|c|}
\hline \multirow[t]{2}{*}{ Gender } & \multicolumn{2}{|c|}{ Age } & & Business \\
\hline & $25-40$ & $\begin{array}{l}40 \text { - and } \\
\text { more }\end{array}$ & \multirow{3}{*}{$\begin{array}{l}\text { Russia, Belorussia, } \\
\text { USA, Singapore, } \\
\text { China, Germany, } \\
\text { Kazakhstan, the } \\
\text { UK. }\end{array}$} & \multirow{3}{*}{$\begin{array}{c}\text { IT sector, } \\
\text { pharmaceutical } \\
\text { industry, educational } \\
\text { business, banking } \\
\text { business, manufacturing } \\
\text { industry. }\end{array}$} \\
\hline Male & $\begin{array}{c}52 \\
(\mathrm{MA}=34)\end{array}$ & $\begin{array}{c}21 \\
(\mathrm{MA}=47)\end{array}$ & & \\
\hline Female & $\begin{array}{c}22 \\
(\mathrm{MA}=29)\end{array}$ & $\begin{array}{c}8 \\
(\mathrm{MA}=43)\end{array}$ & & \\
\hline
\end{tabular}

The second part of the questionnaire was compiled in the form of multiple-choice options with five variants:

Absolutely disagree;

More disagree than agree;

Both agree and disagree;

More agree than disagree;

Absolutely agree.

One of the above-mentioned options were asked to choose while answering the questions. The questions will be presented with the responses of the respondents in the next section; also, the analysis of the responses will be presented there.

Below, one can see the questions of the questionnaire with the total percentage of positive answers (More agree than disagree; Absolutely agree) to these questions: 
Table 2: Questionnaire with the total percentage of positive answers

\begin{tabular}{|c|l|c|}
\hline № & \multicolumn{1}{|c|}{ Questions } & $\begin{array}{c}\text { Total } \\
\text { percentage } \\
\text { of positive } \\
\text { answers }\end{array}$ \\
\hline 1. & $\begin{array}{l}\text { The main challenge for a virtual team is the difference in time } \\
\text { zones. }\end{array}$ & $82,1 \%$ \\
\hline 2. & Culture differences are the main challenges for a virtual team. & $43,7 \%$ \\
\hline 3. & $\begin{array}{l}\text { While communicating with my colleagues I have never come } \\
\text { across something that I do not understand. }\end{array}$ & $73 \%$ \\
\hline 4. & $\begin{array}{l}\text { My colleagues have never complained that they do not } \\
\text { understand me. }\end{array}$ & $69,5 \%$ \\
\hline 5. & $\begin{array}{l}\text { In my company, there have almost never been any } \\
\text { misunderstandings among colleagues arising from differences } \\
\text { in cultures and nationalities. }\end{array}$ & $64 \%$ \\
\hline 6. & $\begin{array}{l}\text { My colleagues have never complained that my gesticulation } \\
\text { and gestures baffle them. }\end{array}$ & $78 \%$ \\
\hline 7. & $\begin{array}{l}\text { In the process of discussion, my colleagues express their } \\
\text { thoughts clearly, leaving no room for personal interpretation. }\end{array}$ & $81 \%$ \\
\hline 8. & $\begin{array}{l}\text { The language and the content of all reports and memos are } \\
\text { subjected to the rules of the company. }\end{array}$ & $76,2 \%$ \\
\hline 9. & $\begin{array}{l}\text { I use the language temples recommended by my company } \\
\text { while working with written documents. }\end{array}$ & $66,3 \%$ \\
\hline 10. & $\begin{array}{l}\text { I use "speech-prompts" templates while communicating with } \\
\text { my fellow-workers. }\end{array}$ & $61,8 \%$ \\
\hline
\end{tabular}

As seen from the results presented in Table 2, time differences create the greatest inconvenience for virtual team workers - they have to make appointments beforehand to communicate, what is extremely embarrassing in urgent situations. Virtual team employees have to look for a time slot in order to get in touch and to discuss some issues. Cultural and national differences are not relevant compared to technical problems. It is really so, since business virtual communication is well structured and almost deprived of national colorings. The main benefit of the loss of colorings is that it helps employees to be focused on creating products and problem-solving.

In this part of the research, we are going to consider how a written language product is organized in an international company, which has the aim of unifying communication flows. We have noted three possible options for organizing a written language product in an international company; these options are also introduced in the work of virtual teams. The first option: the PR department of an international company can develop the samples for correspondence, for example, in the company "Epam Systems" there are samples for writing mimeos, reports and even warnings. For instance, if a work is not completed or delayed, or if a project contains shortcomings, employees receive a warning written in the standard form. The second option is when an international company's management addresses a specialized company that works out the samples of organizational and business correspondence for a client company. This procedure is observed to take into account the specifics of an international company's work. At last, in order to structure business communication, an international company may address the recommendations of special online resources, as, for example the following: https://www.pipefy.com/templates/it-problem-management/. There have been collected the samples of written communication in various spheres of business (for example, IT \& Software, Marketing \& Sales, Operations, Human Resources) and

XLinguae, Volume 12 Issue 1, January 2019, ISSN 1337-8384, eISSN 2453-711X 
recommended formats (templates) for documentation in various cases of business activity.

For example, for the "IT and Software" area, 33 samples are offered in different situations: IT problem management, IT change request, IT Release Management, IT Tickets - incident request, IT Tickets - service request, Helpdesk (tracking receiving emails), IT customer relationship management, IT change request, Application development process, IT project request, IT Onboarding, User Studies, Software deployment For instance, in IT Project Request Sample Structure, the following sections are proposed: Start form, Documentation analysis, Pending data, Characteristics, Committee, Approved, Rejected.

Within each form, several items are recommended to address. For instance, within the section "Start Form", it is obligatory to deal with the following information:

1. Requester name.

2. Requester email.

3. Project name.

4. Request reason.

5. Project description.

6. What is the desired size for this project?

7. Estimated man-hours.

8. Optimal starting date;

9. What is the TI area for this request?

10. Name of the area supervisor.

11. System.

12. Project deadline.

13. Does the project have changes in the data structure?

14. Draft.

The section "Characteristics" requires covering the information on the following issues:

1. Complexity.

2. Technology;

3. Urgency.

4. Cost.

5. Man hours.

These are very illustrative examples of how employees (including virtual team employees) can structure their communication and organize language product. Sure enough, this is done to prevent incomprehension, which happens, inter alia, due to the differences in cultures and mentality of workers. In an international company, many of them represent different nationalities and cultures and live in different cultural and linguistic environments.

Having analyzed some short abstracts of the professional communication of the virtual team members (742 verbal units) we came to the following conclusions. Communication among employees in different situations is built according to a standard algorithm with the use of certain language material. For example, the negotiations of a representative of a virtual software team developing a software product with a potential customer will necessarily contain such items as "selfpresentation", "appeal to the fact of the meeting", "appeal to the need to purchase a new product", "product presentation", "agreement and price negotiation". (As virtual team members of an international software developing company have mentioned to us, their clients quite often do not know exactly themselves what they want to get, and it may be one of the hurdles for successful cooperation). For example, when discussing options for mutually beneficial cooperation, the following cliché phrases are used as responses to the interlocutor's objections: 
"Could you tell us, please, this is the only reason that keeps you from cooperating or there is anything else?";

"Suppose we settle down this question, however, is there anything else that needs to be discussed?";

"Apparently, our proposal, as a whole is interesting to you; however, would you like to change any details?",

"Could you tell us, please if you have any doubts about our proposal?"

As seen, the choice of the stylistic structure and language matter do not leave any chances for high-contextuality (according to E. Hall (2003)). As seen, all question temples are clear and stick to the point (really, a few chances to beat around the bush). Summing up, the phenomenon of communication in a virtual team attracts the attention of philologists, specialists in the field of communication and linguists studying the features of modern electronic communication in a professional environment. Indeed, it is interesting to analyze the specifics of communication there, forms of interaction, communication channels and outgoing text products. In order to complete their tasks, the members of an international virtual team should communicate quickly and effectively. In order to ensure the work of a virtual company, the employees use such forms of communication as electronic correspondence, what happens in the case of sending regular company documents: memoranda, reports, official business letters, and appeals to co-workers or to the company's management. Such corresponding formalities do not happen on a regular basis but it is a compulsive procedure after completion of the project. Informal communication takes place on the forums of the company's website or in the form of interpersonal chats via messengers. In the case of organizational meetings or brainstorming, communication takes place via video utilities such as Skype, Viber, as well, special teleconferences are organized with all participants of a virtual team or with individual members. However, due to different time zones in which the members of a virtual team are operating, video communication is not used often, it happens only by prior arrangement, or in special cases. Thus, we are dealing with a special form of communication, in which the boundaries of personal and professional communication are blurred, the capabilities of the network environment are leveled and status indicators are liberal. Overall, the situation of communication in a virtual team makes it necessary to reconsider the statement that "...Internet communication is a huge field of creative speech activity, in which each participant has the opportunity to realize his personal language and communication potential, since in this situation, a person's speech behavior is in most cases unlimited by those status-role frames that the non-network environment imposes on him" (Zavyalova, 2011, p. 29) (here and hereinafter the translation of the Russian text is provided by the authors).

The fact of a strong technological impact on the unification of communication is hard to object. Moreover, the modern mediated communication predetermines the character of today's business life. Globalization trends, the rapid improvement of electronic means of communication and the internationalization of the business environment these are all extra-linguistic factors contributing to the leveling of national and cultural differences in the language products of virtual teams.

To the solely linguistic factors, that facilitate the unification of communication, one can attribute the mandatory use of a single language (English) as the main means of communication among the employees of a virtual team (most international companies operating in different regions oblige the employees to use English as business lingua franca within the boundaries of their company). For example, in a German-based electronics company "Robert Bosch GmbH", the official language for communication at a workplace is English, and all documents are required to be prepared in English. Hence, the use of the English language creates the integrated linguistic basis, which

XLinguae, Volume 12 Issue 1, January 2019, ISSN 1337-8384, eISSN 2453-711X 
leaves no chances for cross-cultural clashes. Another solely linguistic factor that drives towards the loss of national colorings in communication is the structuring of business and organizational communication within an international company.

\section{Conclusion}

To conclude, globalization and fast development of new computer technologies have completely reshaped the format of interpersonal, organizational and business communication. "Intensified globalization has been driven forward above all by the development of information and communication technologies that have intensified the speed and scope of interaction between people all over the world" (Giddens, 2009). In relation to virtual teams, globalization is viewed as a chance to build teams without taking into consideration the geographical location of the workers. With the advent of technical innovations, primarily personal computers, and the subsequent emergence of the Internet, the very concept of a communicative act has changed, and a new communicative space has emerged. As a result, there appeared a unified type of communicative behavior and unified types of language products.

The research of the linguistic products of business communication among employees of virtual teams allowed us to draw some conclusions. The globalized character of modern environment allows employees of one international company to be located in different countries and ensure successful cooperation. It happens because the new style of business communication is extremely unified. Language is no longer solely an instrument of communication, but a tool for performing specific business tasks. At the same time, such anthropocentric characteristics as the non-verbal component, the pragmatic aspect, social labeling, and national-cultural specificity disappear from the language as a means of communication of a virtual team. In plus, the elimination of the above anthropocentric markers is a necessary condition for the successful functioning of the virtual team in a particular area. It is obvious that the abovementioned aspects are relevant: new technologies backing, geographical remoteness, cultural diversity and "pigeonhole" task distribution cannot but influence the format of communication and the choice of the language matter. In this article we have shown how preserving the national-cultural specifics is impossible in a virtual format of business communication. Moreover, the loss of colorings is inevitable and can be considered as one of the factors of the successful operation of a virtual team.

\section{Acknowledgment}

The publication has been prepared with the support of the "RUDN University Program 5-100".

\section{Bibliographic references}

ALNUAIMI, O.A. - ROBERT, L.P. - MARUPING, L.M. 2010. Team Size, Dispersion, and Social Loafing in Technology Supported Teams: A Perspective on the Theory of Moral Disengagement. In: Journal of Management Information Systems, vol. 27, pp. 203-230. ISSN 0742-1222.

ANDERSON, A.H. - MCEWAN, R. - BAL, J. - CARLETTA, J. 2007. Virtual Team Meetings: An Analysis of Communication and Context. In: Computers in Human Behavior, vol. 2, pp. 2558-2580. ISSN 0747-5632.

AU, Y. - MARKS, A. 2012. Virtual Teams are Literally and Metaphorically Invisible: Forging Identity in Culturally Diverse Virtual Teams. In: Employee Relations, vol. 34, pp. 271-287. ISSN 0142-5455.

BEESON, M. 2007. Regionalism and Globalization in East Asia: Politics, Security and Economic Development. Basingstoke: Palgrave Macmillan. ISBN-13: 9780230000339 ISBN-10: 0230000339.

BISLEY, N. 2007. Rethinking Globalization. Basingstoke: Palgrave Macmillan. ISBN 9781403986955. 
BOSCH-SIJTSEMA, P.M. - SIVUNEN, A. 2013. Professional Virtual Worlds Supporting Computer-Mediated Communication, Collaboration, and Learning in Geographically Distributed Contexts. In: IEEE Transactions on Professional Communication, vol. 56, pp. 160-175. ISSN: 0361-1434.

BOURN, D. 2011. From Internationalization to Global Perspectives. In: Higher Education Research and Development, vol. 30, n. 5, pp. 559-571. ISSN 0729-4360.

BREU, K. - HEMINGWAY, C.J. 2004. Making Organisations Virtual: The Hidden Cost of Distributed Teams. In: Journal of Information Technology, vol. 19, pp. 191202. ISSN 0268-3962.

CAMERON, J. 2008. Sociology. Cheltenham: Nelson Thornes Ltd. ISBN-10: 0748798323; ISBN-13: 978-0748798322.

CHAFFEY, D. 2015. Digital Business and E-Commerce Management: Strategy, Implementation and Practice. Harlow: Pearson. ISBN 978-0-273-78654-2.

CHANDA, N. 2007. Bound Together - How Traders, Preachers, Adventurers and Warriors Shaped Globalization. Yale: Yale University Press. ISBN 978-0-300-112016

CHIDAMBARAM, L. - TUNG, L. 2005. Is out of Sight, out of Mind? An Empirical Study of Social Loafing in Technology-Supported Groups. In: Information Systems Research, vol.16, n.2, pp. 149-168. ISSN: 1047-7047.

CHIZH, N.V. - SLYSHKIN, G.G. - ZHELTUKHINA, M.R. - PRIVALOVA, I.V. KRAVCHENKO, O.A. 2016. Concept "Medical Museum" as a Sociocultural Phenomenon. In: International Journal of Environmental and Science Education, vol. 11, n. 17, pp. 10529-10538. ISSN 1306-3065.

CHOO, W.C. - BERGERON, P. - DETLOR, B. - HEATON, L. 2008. Information Culture and Information Use: An Exploratory Study of Three Organizations. In: Journal of the American Society for Information Science and Technology, vol. 59, n. 5, pp. 792-804. ISSN 1532-2882.

COOPER, R. 2004. The Breaking of Nations: Order and Chaos in the Twenty-first Century. London: Atlantic Books. ISBN 0-87113-913-8.

COOREN, F. - MATTE, F. - BENOIT-BARNÉ, C. - BRUMMANS, B.H. 2013. Communication as Ventriloquism: A Grounded-In-Action Approach to the Study of Organizational Tensions. In: Communication Monographs, vol. 80, n. 3, pp. 255-277. ISSN 03637751.

COOREN, F. 2012. Communication Theory at the Centre: Ventriloquism and the Communicative Constitution of Reality. In: Journal of Communication, vol. 62, pp. 112. ISSN 0021-9916

CULTURE MATTERS: TRAINER'S GUIDE. 1999. Washington: Peace Corps Information Collection and Exchange. ISBN 9781428926936.

FIRSOVA I. - VASBIEVA D. - PROKOPYEV A.I. - ZYKIN E.S. - MATVIENKO V.V. 2018. Development of Consumers' Behavior Business Model on Energy Market. In: International Journal of Energy Economics and Policy, vol. 8, n. 4, pp. 227-233. ISSN 21464553.

GARSIYA-KASELES, K. 2015. Radical, Right movement of Spanish Confederation of Autonomous Right (CEDA) in Spain in the context of political linguistics. (The early XX century). In: Science and Education. Munich, Germany, March $19^{\text {th }}-20^{\text {th }}$, 2015, pp. 235-239. ISBN 978-3-941352-21-6.

GIDDENS, A. 2009. Sociology. Cambridge: Polity Press. ISBN 9780745643571

GILSON, L. - MAYNARD, M. - YOUNG, N. 2015. Virtual Teams Research. In: Journal of Management, vol. 41, n. 5, pp. 1313-1337. ISSN 01492063.

GRINBERG, T.E. 2012. Communication Concept of Public Relations: Models, Technologies, Synergetic Effect. Moscow: Publishing House of Moscow State University. ISBN 978-5-211-06399-0

XLinguae, Volume 12 Issue 1, January 2019, ISSN 1337-8384, eISSN 2453-711X 
GRINBERG, T.E. 2018. Political Technologies. Moscow: Aspect-Press. ISBN: 9785-7567-0948-3

GURA, R. - ROSTEKOVA, M. 2018. Francuzsky model profesionalizacie terciarneho vzdelavania na Slovensku. In Politicke vedy. Vol. 21, No. 3, 2018. ISSN 1335 - 2741, pp. 236-244. Available online: http://doi.org/10.24040/politickevedy.2018.21.3.236-244

HALL, E.T. - HALL, M.R. 1990. Understanding Cultural Differences. Yarmouth, Maine: Intercultural Press. ISBN 1877864072.

HALL, E.T. 2003. Beyond Cultures. Garden City: Anchor Press. ISBN 0844665517, 9780844665511.

HELD, D. - MCGREW, A. 2007. Globalization/Anti-globalization: Beyond the Great Divide. Cambridge: Polity Press. ISBN 9780745639116.

HOFSTEDE G. 2001. Culture's Consequences: Comparing Values, Behaviors, Institutions and Organizations across Nations. Thousand Oaks: Sage. ISBN 080397323-3.

HOFSTEDE, G. 1991. Cultures and Organizations: Software of the Mind. London: McGraw-Hill. ISBN-10: 0071664181. ISBN-13: 978-0071664189.

KARAPETYAN, V.S. - DALLAKYAN, A.M. - ISPIRYAN, M.M. AMIRAGHYAN, M.G. - ZHELTUKHINA, M.R. 2018. The Prospective of the Investment of Contemporary Paradigm of Preschool Education in Future Armenia. In: Astra Salvensis, vol. 4, no. 2, p. 381-390. ISSN 2457-9807. ISSN-L 2457-9807.

KIETZMANN, J.H. - HERMKENS, K. - MCCARTHY, I. - SILVESTRE, B.S. 2011. Social Media? Get Serious! Understanding the Functional Building Blocks of Social Media. In: Business Horizons, vol. 54, n. 3, pp. 241-251. ISSN 0007-6813.

KOZINETS, R.V. - DE VALCK, K. - WOJNICKI, A. - WILNER, S. 2010. Networked Narratives: Understanding Word-of-Mouth Marketing in Online Communities. In: Journal of Marketing, vol. 74, n. 2, pp. 71-89. ISSN 0022-2429.

KOZINETS, V.R. 2010. Netnography Doing Ethnographic Research Online. London: Sage publication Ltd. ISBN-13: 978-1848606456 ISBN-10: 1848606451.

LAPHAM, L. 1994. The Eternal Now. Introduction to the MIT Press Edition. London: The MIT Press. ISBN 0-262-63159-8.

LECHNER, F. 2009. Globalisation: the Making of World Society. Malden: WileyBlackwell. ISBN: 978-1-405-16905-9.

MANAGEMENT STUDY GUIDE. 2017. Available online: http://www.managementstudyguide.com/virtual-team.htm

MARTINS, L.L. - SHALLEY, C.E. 2011. Creativity in Virtual Work: Effects of Demographic Differences. In: Small Group Research, vol. 42, pp. 536-561. ISSN 1046-4964.

MCLUHAN, M. 1962. The Gutenberg Galaxy: The Making of Typographic Man. Toronto: University of Toronto Press. ISBN 0-8020-6041-2.

MCLUHAN, M. 1964. Understanding Media: The Extensions of Man. Canada: McGraw-Hill. ISBN 0262631598.

MCLUHAN, M. 1994. Understanding Media: The Extensions of Man. Cambridge: The MIT Press. ISBN 0-262-63159-8.

MOCKAITIS, A.I. - ROSE, E.L. - ZETTINIG, P. 2012. The Power of Individual Cultural Values in Global Virtual Teams. In: International Journal of Cross Cultural Management, vol. 12, pp. 193-210. ISSN 1470-5958.

MUETHEL, M. - GEHRLEIN, S. - HOEGL, M. 2012. Socio-Demographic Factors and Shared Leadership Behaviors in Dispersed Teams: Implications for Human Resource Management. In: Human Resource Management, vol. 51, pp. 525-548. ISSN 0954-5395.

NATHAN, M. - ROSSO, A. 2014. Mapping Digital Businesses with Big Data: Some Early Findings from the UK. In: Research Policy, vol. 12, pp. 124. ISSN 0048-7333. 
OSTRIKOVA, G.N. - ZHELTUKHINA, M.R. - ZYUBINA, I.A. - SIDOROVA I.G. 2018. Learning Via Visualization at the Present Stage of Teaching a Foreign Language. In: Astra Salvensis, vol. 4, no. 1, pp. 601-607. ISSN 2393-4727.

PAGANI, M. 2013. Digital Business Strategy and Value Creation: Framing the Dynamic Cycle of Control Points. In: MIS Quarterly: Management Information Systems, vol. 37, n. 2, pp. 617-632. ISSN 0276-7783.

POWELL, A. - PICCOLI, G. - IVES, B. 2004. Virtual Teams: a Review of Current Literature and Directions for Future Research. In: SIGMIS Database, vol. 35, n. 1, pp. 6-36. ISSN 1532-0936.

PRIDMORE, J. - PHILLIPS-WREN, G. 2011. Assessing Decision-Making Quality in Face-To-Face Teams Versus Virtual Teams in a Virtual World. In: Journal of Decision Systems, vol. 20, pp. 283-308. ISSN 1246-0125.

PRIVALOVA, I.V. 2012. Cultural Peculiarities of Russian Audience Participation in Political Discourse in the Era of New Technologies. In: Cheong P. H., Martin, J. N., \& Macfadyen L.P. (Eds.). New Media and Intercultural Communication: Identity, Community and Politics. New York: Peter Lang. ISBN 978-1-4331-1365-9

RITZER, G. 2010. Globalisation. Malden: Wiley-Blackwell. ISBN 978-1-118-687123.

ROBERTSON, R. 1992. Globalization: Social Theory and Global Culture. London: Sage. ISBN 0-8039-8187-2.

ROSTEKOVA, M. 2018. Francuzsko-slovenska spolupraca ako motor internacionalizacie vysokoskolskeho vzdelavania na Slovensku. In Politicke vedy. Vol. 21, No. 1, 2018. ISSN 1335 - 2741, pp. 204-211. Available online: http://dx.doi.org/10.24040/politickevedy.2018.21.1.204-211

RUGGIERI, S. 2009. Leadership in Virtual Teams: A Comparison of Transformational and Transactional Leaders. In: Social Behavior and Personality, vol. 37, pp. 1017-1022. ISSN 0301-2212.

SCHOLTE, J.A. 2005. Globalization: A Critical Introduction. Basingstoke: Palgrave Macmillan. ISBN 1403904480.

SHAO, G. 2009. Understanding the Appeal of User-Generated Media: a Uses and Gratification Perspective. In: Internet Research, vol. 19, n. 1, pp. 7-25. ISSN 10662243.

ST. AMANT, K. 2012. Culture, Context and Cyberspace: Rethinking Identity and Credibility in International Virtual Teams. In: Cheong P.H., Martin, J.N., \& Macfadyen L.P. (Eds.). New Media and Intercultural Communication: Identity, Community and Politics. New York: Peter Lang. ISBN 978-1-4331-1365-9.

STEGER, M. 2010. Globalisation: A Very Short Introduction. Oxford: OUP. ISBN 13: 9780199662661.

STIGLITZ, J. 2006. Making Globalization Work. London: Penguin Books. ISBN 13: 978-0-393-06122-2.

STRANG, K.D. 2011. Leadership Substitutes and Personality Impact on Time and Quality in Virtual New Product Development Projects. In: Project Management Journal, vol. 42, pp. 73-90. ISSN: 1938-9507.

TARDE, G. 1969. On Communication and Social Influence. Chicago: University of Chicago Press. ISBN 0226789713.

THOMPSON, J. 1995. The Media and Modernity. Cambridge: Polity Press. ISBN: 9780804726795.

TIDD, J. - BESSANT, J. 2014. Strategic Innovation Management. New York: John Wiley \& Sons. ISBN: 047-0093269, 978-0470093269.

VELIEVA, S.V. - MASHKIN, N.A. - KHAIRULLINA, E.R. - SEMENOVA, T.N. - VARLAMOVA, M.E. - GUSEVA, T.S. - DOLGASHEVA, M.V. 2018. University student professional selfactualization: Context of personality subjectivity. In: Espacios, vol. 39, n. 20, article number 12. ISSN: 0798-1015.

XLinguae, Volume 12 Issue 1, January 2019, ISSN 1337-8384, eISSN 2453-711X 
ZAVYALOVA, Z.S. 2011. Features of Self-Presentation of an Individual under the Conditions of Internet Communication: PhD Thesis. Tomsk.

ZHELTUKHINA, M.R. - SLYSHKIN, G.G. - PONOMARENKO, E.B. BUSYGINA, M.V. - OMELCHENKO, A.V. 2016. Role of Media Rumors in the Modern Society. In: International Journal of Environmental and Science Education, vol. 11, n. 17, pp. 10581-10589. ISSN 1306-3065.

Words: 6728

Characters: 46452 (25,81 standard pages)

Prof. Irina Vladimirovna Privalova, DrSc.

Russian as a Foreign Language Department

Saratov State Medical University named after V.I. Razumovski

Bolshaya Kazachia Street 112

410012 Saratov

Russia

ivprivalova@mail.ru

Prof. Albina Rafisovna Shaidullina, DrSc.

Department of Foreign Languages

Almetyevsk State Oil Institute

Lenin Street 2

423450 Almetyevsk

Russia

albina-plus@mail.ru

Prof. Marina Rostislavovna Zheltukhina, DrSc.

Foreign Languages Institute

Volgograd State Socio-Pedagogical University

Lenin Avenue 27

400066 Volgograd

Russia

zzmr@mail.com

Prof. Tatyana Eduardovna Grinberg, DrSc.

Faculty of Journalism

M.V. Lomonosov Moscow State University

Mokhovaya Street 9/1

125009 Moscow

Russia

gritajourn@mail.ru

Associate Prof. Conchita García Caselles, PhD.

Faculty of Philology

Peoples' Friendship University of Russia (RUDN University)

Mikluho-Maclay Street 6

117198 Moscow

Russia

konchitag@mail.ru 